\title{
О НЕОБХОДИМОСТИ УЧЕТА ФАКТОРА ИСТОЩЕНИЯ РЕСУРСНОЙ БАЗЫ УГЛЕВОДОРОДНОГО СЫРЬЯ ДЛЯ ОБЕСПЕЧЕНИЯ ДОЛГОСРОЧНОГО РЕГИОНАЛЬНОГО РАЗВИТИЯ"
}

\author{
(C) 2018 Цибульникова Маргарита Радиевна \\ кандидат географических наук, доцент отделения нефтегазового дела \\ НИ Томский политехнический университет (отделение нефтегазового дела) \\ 634050, г. Томск, пр. Ленина, 30 \\ E-mail: tsibulnikova2011@yandex.ru \\ (c) 2018 Шарф Ирина Валерьевна \\ кандидат экономических наук, доцент отделения нефтегазового дела \\ НИ Томский политехнический университет (отделение нефтегазового дела) \\ 634050, г. Томск, пр. Ленина, 30 \\ E-mail: irina_sharf@mail.ru
}

Обосновывается необходимость исследования влияния фактора истощения запасов минерально-сырьевых ресурсов на параметры социально-экономического развития территории сырьевой специализации. В качестве примера рассматривается Томская область в контексте взаимосвязей недропользования с социально-экономическим развитием ее территории. Особое внимание уделено экономической оценке истощения запасов нефти. Приводятся расчеты с использованием различных методов и их сравнительный анализ. Обосновывается подход к учету результатов оценки истощения минерально-сырьевой базы региона в распределении рентных доходов между федеральным и региональным бюджетами.

Ключевые слова: природный фактор, природопользование, истощение запасов нефти, экономическая оценка, рентные доходы, территориальное развитие, государственное регулирование.

\section{Введение}

В отечественной и зарубежной научной литературе отмечается не только значимость природного фактора в развитии территорий, но и анализируется его многоаспектное влияние на социально-экономическое развитие регионов [14].

Величина и разнообразие природно-ресурсного потенциала являются существенными факторами устойчивого регионального развития[2] Благодаря хозяйственной деятельности человека природные ресурсы региона составляют основу формирования территориально производственных комплексов [7]. В регионах сырьевой специализации природный фактор играет ключевую роль в формировании рыночного потенциала и определяет его специализацию. Часто, использование природных ресурсов территорий сырьевой специализации не способствует их развитию в долгосрочной перспективе [6, 9, 21, 22].
Наиболее подробно влияние сырьевого фактора развития исследовано в работах Г.А. Приваловской и И.Н. Волковой [13]. Анализируя различные теории влияния сырьевого сектора на экономику, авторы отмечают, что в России этим вопросам не уделяется внимание и, фактически, игнорируется вопрос о судьбах сырьевых регионов. Рассматривая социальные последствия истощения ресурсов для данных регионов, авторы делают выводы о том, что принятие управленческих решений должно основываться на учете показателей истощения природных ресурсов конкретной территории [12] и использовании рентных доходов от добычи полезных ископаемых [14, 20]. Проблема справедливого распределения рентных доходов остается актуальной и нерешенной до настоящего времени и является тематикой научных дискуссий $[8,9,11$, 17].

Согласно концепции устойчивого развития

\footnotetext{
Статья выполнена в рамках гранта РФФИ 18-010-00660 А Концептуальные подходы к парадигме устойчивого и сбалансированного недропользования области с учетом специфики минерально-сырьевой базы и отраслевой структуры в целях обеспечения долгосрочного социально-экономического роста нефтедобывающего региона. Регистрационный номер ЦИТиС АААА-А17-117122990012-5.
} 
при наличии истощения запасов часть ренты от эксплуатации невозобновимых ресурсов следует реинвестировать в развитие территории для обеспечения ее долгосрочного функционирования после исчерпания запасов. Фактор истощения необходимо учитывать при формировании бюджетно-налоговой политики государства. В этой связи важны более детальные региональные исследования с целью разработки предложений по распределению доходов между федеральным центром и ресурсными регионами, чтобы не допустить их деградации после истощения запасов природных ресурсов $[3,10]$.

Для территорий, зависящих от невозобновимых природных ресурсов, необходимы меры, которые позволят обеспечить их долгосрочное развитие после истощения месторождений полезных ископаемых. Поэтому для добывающих регионов при разработке стратегий и планов развития представляется целесообразным проводить расчеты истощаемости природных ресурсов.

\section{Материалы и методы}

В настоящей статье использованы материалы докладов о состоянии минерально-сырьевой базы и о состоянии окружающей среды Томской области, ведомственная информация, нормативные документы, отражающие социально-экономическое развитие Томской области в контексте использования ее природного капитала.

Для расчета показателей истощения ресурсов нефти для Томской применены методы: издержек пользователя; чистой цены; текущей стоимости. Данный методический подход предложен Всемирным банком для оценки проектов, связанных с использованием невозобновляемых ресурсов [5]. Согласно мировой практике, если срок эксплуатации ресурса более 50 лет, то показатель истощения можно не учитывать при корректировке валового внутреннего продукта. В обратном случае, при планировании социально-экономического развития необходимость учета истощения минерально-сырьевой базы очевидна [19].

Роль добычи нефти в экономике Томской области

Томская область расположена на юге Западной Сибири в бассейне р. Оби. Нефтегазовая отрасль является основным фактором формирования ВРП региона. В структуре валовой добавленной стоимости преобладает добыча полезных ископаемых (29,5\%), где доля топлив- но-энергетических полезных ископаемых составляет 99,6\% от общего объема. В последние годы в нефтедобывающей отрасли отмечается снижение индекса производства, объема инвестиций в основной капитал, увеличение изношенности основных фондов [18].

Динамика снижения уровней добычи нефти за последние пять лет в среднем составляет 200 тыс.т. в год. В 2016 году добыто 10,4 млн.т., а прирост запасов составил только около 50\%. Большая часть относительно крупных месторождений выработана на 70\% и более. Запасы углеводородного сырья в Томской области относятся к категории трудно извлекаемых, что требует повышенных затрат на добычу и снижает возможности недропользователей проводить работы по расширенному воспроизводству минерально-сырьевой базы [4].

Налог от добычи углеводородного сырья (НДПИ) полностью зачисляется в федеральный бюджет [23]. Отметим, что до 2010 г. доля региональных бюджетов от НДПИ по нефти составляла 5\% и по сумме была сопоставима с доходами от налога на прибыль. С территории Томской области от НДПИ в виде углеводородного сырья в 2015 г. и 2016 г. в федеральный бюджет поступило, соответственно, 65,3 млрд. руб. и 52,8 млрд. руб., что сопоставимо с размером всего бюджета области (в 2015 году областной бюджет составил 61,4 млрд. руб.).

Экономическая оценка истощения запасов нефти в Томской области

Каждый из методов оценки применяется с определенными допущениями и имеет свои достоинства и недостатки.

Метод издержек пользователя предполагает сохранение текущего уровня ренты до полного исчерпания запасов ресурса. Метод предложен El. Serafy (Всемирный банк) и широко применяется в мировой практике [19]. Показатель истощения U (тыс.руб./год) рассчитывается по формуле:

$$
\mathrm{U}=\mathrm{R} /(1+\mathrm{s})^{\mathrm{T}} \text {, }
$$

где: $\mathrm{R}$ - экономическая рента за ресурс, тыс. руб. /год; s - ставка дисконта, величина ставки дисконтирования рассчитывается в соответствии с общепринятыми подходами к оценке инвестиционных проектов и представляет собой корректировку стоимости ресурса в будущих периодах на величину, учитывающую темпы инфляции, банковский процент по вкладам и другие факторы. Нами для расчетов принято 
$s=15 \%$; T - прогнозный срок эксплуатации месторождения (лет), который определяется делением величины остаточных запасов полезных ископаемых (358,8 млн. т) на объем добычи, среднегодовая добыча за последние пять лет 10,9 млн.т., соответственно T=33 года.

Расчет ренты проведен на основе данных о себестоимости добычи АО «Томскнефть»ВНК. Исходя из показателей запасов и среднегодовой добычи при цене нефти на внешнем рынке чистая стоимость (рента) составила 12385руб./т. (стоимость 1т. нефти составляет 368 долл./т, $\$ 1=51,2$ руб.) при допущении, что цены не изменятся в течение всего расчетного периода (Т). Среднегодовая рента составит 135 млрд. руб. Величина истощения, рассчитанная на основе полученных данных составит соответственно: $\mathrm{U}=135 /(1+0,15)^{33}=1,3$ млрд/год.

С 2013 года объемы добычи нефти в Томской области превышают объемы воспроизводства запасов. В случае превышения объемов изъятия над объемами воспроизводства природных ресурсов в составе природного капитала какой-либо территории применяется метод текущей стоимости. Метод основан на допущении, что рыночные цены на сырье и издержки по его добыче постоянны, а уровни добычи снижаются. Нами приняты допущения, что ежегодное снижение будет происходить на уровне 0,2 млн.т без воспроизводства запасов. Показатель истощения запасов U (тыс. руб./год) в году t рассчитывается по формуле:

$$
\mathrm{U}_{\mathrm{t}}=\mathrm{R}_{\mathrm{t}}-(\mathrm{s} /(1+\mathrm{s})) * \mathrm{~V}_{\mathrm{t}+1} \text {, }
$$

где: $\mathrm{R}_{\mathrm{t}}$-экономическая рента за ресурс в году t (тыс. руб./год); s - ставка дисконта,\%. Для расчета принята на уровне $15 \% . \mathrm{V}_{\mathrm{t}+1}-$ текущая стоимость запасов ресурса в году $\mathrm{t}+1$ (тыс. руб./ год).

Стоимость запасов рассчитана как капитализированная рента по формуле:

$$
\mathrm{V}=\sum_{\mathrm{t}=0}^{\mathrm{T}} \frac{\mathrm{R}_{\mathrm{t}}}{-(1+\mathrm{e})^{\mathrm{t}}}
$$

где: $\mathrm{R}_{\mathrm{t}}-$ рента, приносимая природным объектом в году $\mathrm{t}$; $\mathrm{T}$ - период эксплуатации природного объекта; е - ставка дисконтирования.

Для экономической оценки запасов ставка дисконта принимается на уровне $3 \%$. Нами получено значение текущей стоимости запасов 2058 млрд. руб. $U=135-0,13 * 2058=135-267,5=-132$.

Полученные отрицательные значения ука- зывают на то, что экономический срок истощения запасов в 2,5 раза меньше физического. Если принять во внимание, что в среднем по области коэффициент нефтеизвлечения составляет 0,3, то при заданных прогнозных параметрах разработка действующих месторождений может прекратиться к 2025-2026 г.г.

Для уточнения прогнозов применяется метод чистой цены. Истощение запасов определяется как произведение удельной ренты на изменение объема достоверных запасов. При этом в расчете не учитываются срок эксплуатации ресурса и ставка дисконта. Показатель истощения рассчитывается по формуле:

\section{$\mathrm{U}=\mathrm{UR} *(\mathrm{D}-\mathrm{N})$,}

где: UR - рента за единицу добываемого ресурса, тыс. руб./ед.; UR=12385 руб.; D - годовой объем добычи ресурса, ед./год; D =10,5 млн. т; N - достоверные запасы новых месторождений, ед; N=5 млн.т; $\mathrm{R}$ - экономическая рента за ресурс. В результате расчетов получены следующие значения: $\mathrm{U}=12385$ руб * $(10,5-5)=68,1$ млрд. руб.

Таким образом, величина истощения запасов составила в 2016 году 68,1 млрд. руб./год и составляет $14 \%$ ВРП. Полученные результаты показывают, что прирост ВРП получен за счет истощения минерально-сырьевой базы Томской области. Если бы истощение запасов полезных ископаемых учитывалось при расчете ВРП, то индекс физического объема валового регионального продукта в процентах к предыдущему году составил бы 86\%. Метод чистой цены отражает текущую ситуацию и эффективен для оценки результатов использования минерально-сырьевой базы в текущем году.

Показатели истощения рассчитанные различными методами указывают на то, что наиболее благоприятная экономическая ситуация для области будет складываться при постоянных высоких ценах на нефть и уровнях добычи на уровне 10 млн. т. в течении 33 лет при ежегодном истощении запасов в 1,3 млрд. руб. (метод издержек пользователя). Но если рассматривать ситуацию в условиях снижения уровней добычи без воспроизводства, то к 2026 году неизбежно наступит резкое падение рентабельности добычи нефти. На это указывают отрицательные значения, полученные методом текущей стоимости. Если при расчете среднего ежегодного уровня экономического истощения запасов использовать $\mathrm{T}=10$, то получим значение 33,8 млрд. руб./ 
год (половина бюджета Томской области). Согласно расчетам истощения запасов нефти для создания условий устойчивого развития региона в настоящее время как минимум 50\% от НДПИ необходимо направлять на развитие Томской области в виде инвестиций в строительство объектов обрабатывающей промышленности и развитие инфраструктуры региона.

В целом в России увеличивается количество месторождений с падающей добычей, наблюдается качественное ухудшение минерально-сырьевой базы углеводородного сырья. За истощением запасов углеводородного сырья последует и сокращение и других производств, которые тесно связаны с нефтегазодобывающим комплексом. В перспективе, через 30-35 лет 15\% территории России лишившись основных природных ресурсов, обеспечивающих их развитие, могут превратиться в депрессивные территории с интенсивным оттоком населения [15].

Показатели истощения минерально-сырьевой базы могут быть рассмотрены в качестве критериев, указывающих на необходимость принятия решения по введению специальных мер для обеспечения устойчивости развития территорий сырьевой специализации в долгосрочной перспективе.

\section{Заключение}

В сложившихся экономических условиях добыча углеводородного сырья будет являться основным источником доходов бюджета еще длительное время. Поэтому важно учитывать фактор истощения минерально-сырьевой базы в территориальном развитии.

Исследования эколого-социально-экономического развития Томской области показали, что положительная динамика макроэкономических показателей не способствует устойчивому развитию территории Томской области. Снижается уровень жизни большей части населения, среднедушевые денежные доходы ниже средних по России. Данная тенденция указывает на необходимость принятия превентивных мер, которые позволят поддержать сложившийся уровень развития после исчерпания запасов и предотвратить переход региона в разряд депрессивных.

Сравнения с другими нефтегазодобывающими регионами с высокой долей нефтегазодобывающей промышленности в структуре ВПР отражают наличие сходных тенденций, в том числе, замедляются темпы роста в обрабатывающей промышленности, увеличивается разрыв между ВРП на душу населения и фактической покупательной способностью на душу населения. Данные критерии могут быть использованы для выделения группы регионов, где необходима разработка индивидуальных программ диверсификации экономики.

В контексте распределения рентных доходов следует разработать индивидуальный подход к сырьевым территориям. В качестве определения минимального значения для принятия решения о доле средств, которые будут направлены на развитие территории, может быть предложен расчет истощения запасов полезных ископаемых. Данный подход применим в случае, если срок их эксплуатации менее 50 лет. Для таких случаев законодательно следует закрепить принцип индивидуального расчета доли дохода от налога на добычу полезных ископаемых, которая будет направлена на развитие территории.

\section{Библиографический список}

1. Адам А.М., Цибульникова М.Р. Обоснование необходимости перераспределения налога на добычу углеводородного сырья между федеральным и региональным бюджетами на примере Томской области // Минеральные ресурсы России. Экономика и управление. 2006. № 2. С. 72-73.

2. Бакланов П.Я. Географические и геополитические факторы в региональном развитии//Региональные исследования. 2014. № 2. С. 4-10.

3. Волконский В.А., Кузовкин А.И., Мудрецов А.Ф. Природная рента и методы ее оценки// Проблемы прогнозирования. 2005. № 1 . С. 50-61.

4. Государственный доклад «О состоянии и охране окружающей среды Томской области в 2015 году». Томск. 2016. 156 с.

5. Диксон Д. А., Скура Л.Ф., Карпентер Р.А. Экономический анализ воздействий на окружающую среду. Москва. 2000. 272 с.

6. Зубаревич Н.В., Сафронов С.Г. Территориальное неравенство доходов населения России и других крупных постсоветских стран// Региональные исследования. 2014. № 4 (46). С. 100-110. 
7. Игнатьева М.Н. Формирование природного потенциала территории//Известия Уральского Государственного горного университета. 2014. № 4(36). С. 51-55.

8. Кимельман С.А. Сырьевой сектор экономики России: состояние и возможности развития // Экономика региона № 4. 2010. С. 173-182

9. Крюков В. А., Севастьянова А.Е., Токарев А.Н. Современный подход к разработке и выбору стратегических альтернатив развития ресурсных регионов // Экономика региона. 2017. Т. 13. вып. 1. С. 93-105.

10. Кузнецова О.В. Региональная политика России: дискуссионные вопросы современного этапа развития// Региональные исследования. 2016. № 4 (54). С. 10-16.

11. Львов Д. С., Кимельман С.А., Пителин А.К. О проблеме рентного налогообложения//Экономическая наука современной России. 2004. № 3. С. 5-16.

12. Приваловская Г.А., Волкова И.Н. Влияние ресурсопользования на социально экономическое развитие сырьевых регионов // Из-во. РАН. Сер. геогр. 2004. С. 5-16.

13. Приваловская Г. А., Волкова И.Н. Социально-экономические предпосылки рисков устойчивого развития регионов России // Известия Российской Академии наук. Серия географическая. 2010 № 3. С. 8-20.

14. Природопользование в территориальном развитии современной России: / Под ред. И.Н. Волковой, Н.Н. Клюева. М.: Медиа Пресс. - 2014.- 360 с.

15. Рахманкулов, Д. Л., Николаева С.В., Латыпова Ф.Н., Вильданов Ф.Ш. О проблеме истощения мировых запасов нефти. Башкирский химический журнал. 2008. Том 15. № 25 с. 5-35.

16. Регионы России. Социально-экономические показатели. Стат. сб. / Росстат. 2016. 1326 с.

17. Татаркин А.И. Региональная направленность экономической политики Российской Федерации как института пространственного обустройства территорий//Экономика региона. 2016. Т. 12, Вып. 1. С. 9-27

18. Томская область в цифрах. Крат.стат.сб./Томскстат. Томск. 2016. 252 с.

19. El. Serafy. The proper calculation of income from depletable resources/Eds. Y.J. Ahmad, E.S. Serafy, E Lutz. A United Nations Environment Program - World Bank Symposium. Washington, D. C.: World Bank. - 1989.

20. Hartwick J.M. Intergenerational Equity and the Investing of Rents from Exhaustible Resources // The American Economic Review.-1977. V. 67.- N5.-P. 972-974.

21. Janshanlo R.E. The role of natural rent in the economic development of Kazakhstan//Journal of Advanced Research in Law and Economics. . V.7, Issue 2. - 2016. - P. 240-247.

22. Raheem I.D., Isah K. O., Adedeji A.A. Inclusive growth, human capital development and natural resource rent in SSA Economic // Change and Restructuring. - 2016. - № 1. -P. 1-20.

23. Sharf, I.; Grinkevich, L; Tsibulnikova, M.; и др.Tax Burdens of Russian Oil Producing Companies - Comparative Analysis, Proceedings of the 27th Conference International Business Information Management Association. Milan, ITALY, MAY04-05, 2016, p.410-415 